\title{
Problems and Challenges in Skills Development: A Perspective from Professional Accounting Education
}

\begin{abstract}
Gohar Saleem Parvaiz ${ }^{1}$, Owais Mufti ${ }^{2}$, Saleem Gul ${ }^{3}$
Abstract

This study contributes to the theory of constraints by adding a fresh perspective gathered from professional accounting institutions. Professional accounting institutes differ from universities, where most of the earlier research-work regarding constraints in academia has been conducted. To holistically address the study's research question, this research employed a triangulation approach comprised of articulation, 3 cognitive interviews and a survey. During the survey, the data have been collected from 201 academicians teaching in professional accounting institutes of Pakistan. Findings revealed that most of the prevalent constraining elements that are found within the extant literature pertaining to the university education system are noticeably absent in the perspectives of professional accounting institutes. In this research the prevailing constraints include, training organisations not following standard procedures, potential students have misperceptions about accounting education being mathematical in nature, enrolling students have inadequate academic skills, insufficient stipends offered by professional training organisations, accounting institutes are not appreciating teaching activities, and lack of training opportunities for academics.
\end{abstract}

Keywords: Accounting education, constraints, professional accounting, academics, social efficiency ideology

\section{Introduction}

The $21^{\text {st }}$ century has witnessed an increasing influence within educational programs towards 'social efficiency', perhaps due to the dominance of economic and political power (Pinar, 2008). The social efficiency ideology implies a fundamental edict that human life consists in the performance of specific abilities, these may render some people better off than others. Arguably, as education prepares for life, so education should prepare those being educated for certain specific abilities (Schiro, 2012).

1 Assistant Professor, Institute of Management Sciences, Peshawar. Email: gohar.saleem@imsciences. edu.pk

2 Assistant Professor, Institute of Management Sciences, Peshawar. Email: owais.mufti@imsciences.edu. pk

3 Assistant Professor, Institute of Management Sciences, Peshawar. Email: s.gul@imsciences.edu.pk

\begin{tabular}{llll}
\multicolumn{2}{l}{ ARTICLE HISTORY } \\
\hline 30 Jul, 2017 & Submission Received & 6 Oct, 2017 & First Review \\
\hline 1 Nov, 2017 & Revised Version Received & 16 Nov, 2017 & Second Review \\
\hline 6 Dec, 2017 & Revised Version Received & 20 Dec, 2017 & Accepted
\end{tabular}


This phenomenon seems more apparent in professional accounting education where teachers are considered as mere "technicians" with a responsibility to teach 'skills' to students, rendering them fit for employment (Pinar, 2008). Within 'curriculum theory' the 'social efficiency ideology' implies to design an education curriculum intended to maximise the 'social utility or productivity' of an individual as a societal future (Schiro, 2012). In this regard, Lessenger and Salowe (2001) depicted the doctrine of 'social efficiency ideology', by relating employable skills to a quality education system, cited by Schiro (2012) as:

"A quality education system is an absolute essential to the economic, political, and social welfare... there is a consensus that students need employable skills for the new economy" (p. 79)

Similarly, like Lessenger and Salowe (2001), Bui and Porter (2010) advocating the ideology of 'social efficiency' in 'curriculum theory' proposed a theoretical framework titled: 'expectation-performance gap', which intends to investigate the shortfall between accounting employers' expectations regarding skills acquisition for employment purposes and academics' pedagogical ineffectiveness in skills development. In this regard, Parvaiz, Mufti and Wahab (2017) investigated the skills acquisition shortfall in students of professional accounting institutes and found that out of 35 investigated skills, 24 were found to be underdeveloped in students for employment purposes benchmarked against employers' expectations. Thus, this finding, warrants investigating the context of accounting institutes to explore the constraining elements that are hampering the abilities of academicians to develop the skills in students up to the standards of accounting employers. Thus, this phenomenon implies for setting the following question for this research $(R Q)$ as: -

What are the constraints towards skills development from the perspective of professional accounting education?

\section{Literature Review}

In this section, a review of the existing literature is undertaken with the aim to explore the constraints that are hindering the ability of academics towards skills development. However, in this regard, it has been noticed most of the existing literature is written from the contextual focus of university education providers. Whereas, for the reasons outlined above, the setting of the context under this research is a professional accounting institutes.

Accounting literature assumes that academicians are incapable of fostering appropriate skills in accounting students because of the contextual limitations of their jobs. Thus, academicians are not working in isolation, rather they are bound by the 
contextual limitations which affect their ability to develop skills in students (see, Bui \& Porter, 2010; De-Lange, Jackling, \& Gut 2006; Kavanagh \& Drennan, 2007; Millner $\&$ Hill, 2008). Such limitations are identified as constraints. Accounting literature defines constraints as the factors that are limiting the ability of accounting education in the development of skills (Bui \& Porter, 2010). To educate students adequately, it is important to identify such constraints from the academicians' perspective, so that appropriate actions may be undertaken to eradicate them or limit their impact.

In accounting education, there is growing concern that education institutes are not retaining the students possessing the right aptitude in a sufficient quantity to meet the demands of the accounting education (Wells, Gerbic, Kranenburg \& Bygrave, 2009). Declining enrolment rates in accounting education institutes indicate that the accounting profession is diminishing its attractiveness to students. This aspect is well documented in the accounting literature (see Arthur Andersen et al., 1989; Felton, Buhr, \& Northey, 1994; Hermanson et al., 1996; Marriott \& Marriott, 2003; Wells, 2006; ICAA ${ }^{4}, 2002 ;$ Jackling \& Calero, 2006). In this regard, Adams, Pryor and Adams (1994) conducted a longitudinal study of 238 students from an introductory accounting course in the USA. They reported that students leaving the accounting program had on average a higher Grade-Point-Average (GPA) than those who did not leave. However, Riodan, Pierre and Matoney (1996) reported contrary results. Their finding, based on a longitudinal study comprising 4800 students in the USA, is that students entering an accounting program have, on average, higher intellectual abilities than those who did not.

A number of factors are apparent in the literature as constraining elements within education institutions. These vary across institutions based upon their contextual limitations, such as, institution size, and financial resources, etc. (see Street, Baril \& Benke, 1993; Manakyan \& Tanner, 1994; Lindsay \& Campbell, 1995; Hill, 1998; Murdoch \& Guy, 2002). Considering the variability of these constraints, they are further classified into two categories, that is, internal and external constraints.

Internal constraints include class size, research activities, and unrewarded teaching excellence. For example, Murdoch and Guy (2002) investigating student performance based on class size found that students who had been taught in small classes appeared to show better signs of academic achievement. However, in contrast, Hill (1998) did not find that large class size was a constraining factor in academic achievement. Later, work by Milner and Hill (2008) with UK academics, found that the development of skills was impeded by large class sizes. Other researchers, such as Hassall, Joyce, Montaño and Anes (2005) have also identified large class size as a major constraining

4 Trends in accounting at Australian universities: Report presented to Institute of Chartered Accountants in Australia. 
factor in skills development. Manakyan and Tanner (1994) and Lindsay and Campbell (1995) studied the relationship between teaching effectiveness and research activities. Manakyan and Tanner (1994) surveyed 226 accounting educators in the USA and did not find a major difference between research activities and teaching effectively. However, they did report a small but significant, negative relationship between research activities and effective teaching practices. Similarly, Kavanagh and Drennan (2007) found from the Australian accounting academicians' perspective that they were too preoccupied with research activities to keep the curriculum updated in terms of skills development. Other studies reported the lack of an adequate reward system for teaching activities as another constraining factor. Today, endemic dissatisfaction exists among educators over the reward system for effective teaching practices (Seldin, 1995). This dissatisfaction exists because of the persistent undervaluing of teaching excellence and the overvaluing of research activities. In this regard, Porter and Carr (1999) explicitly highlight the importance of having a proper reward system for the development of teaching excellence in accounting education in New Zealand. Similarly, Kavanagh and Drennan (2007) also found from an Australian accounting educators' perspective that having an inadequate reward system for teaching effort is a major reason for teacher ineffectiveness.

External constraining elements are the funding structure of educational institutes, the audit culture and the accreditation standards. For-example Dominelli and Hoogvelt (1996) investigated the effects of a research-based culture, which was triggered by the changes in the UK funding structure for academic financial assistance. They reported that the shift to a research-based culture is one of the primary reasons for a decline in educators' teaching performance. From the literature, another constraining element identified was an ineffective audit culture. For example, Craig and Amernic (2001) found an audit culture, which was focused on quantity and revenue, that is, one based on the number of students and a certain amount in fees. They went on to imply that teaching quality standards were compromised by such a focus. Finally, another constraining element was the nature of accreditation standards of the accounting bodies (Bui \& Porter, 2010). For example, the accreditation standard criteria set by the Association to Advance Collegiate Schools of Business (AACSB) require that $50 \%$ of the credit hours in a four-year curriculum must be outside the accredited accounting college. Further, the program must include at least 30 credit hours with a minimum of 12 hours in an area of specialization and 18 hours in specific core areas (Duncan \& Schmutte, 2006). Similarly, the 150 semester hours learning requirement set by the American Institute of Certified Public Accountants (AICPA) broaden the accounting curriculum to the point where there is a limited space and time for accounting educators to focus on soft skills development. 


\section{Methodology}

To have a holistic view, following the methodological paradigm of pragmatism (see Parvaiz, Mufti \& Wahab, 2016) this research employed a triangulation approach to get the complete understanding of the phenomenon of interest. A triangulation approach implies for using multiple data sources in an investigation for understanding purposes. The triangulation approach used in this study is comprised of articulation, cognitive interviews and a survey to address the research question (see Figure 1).

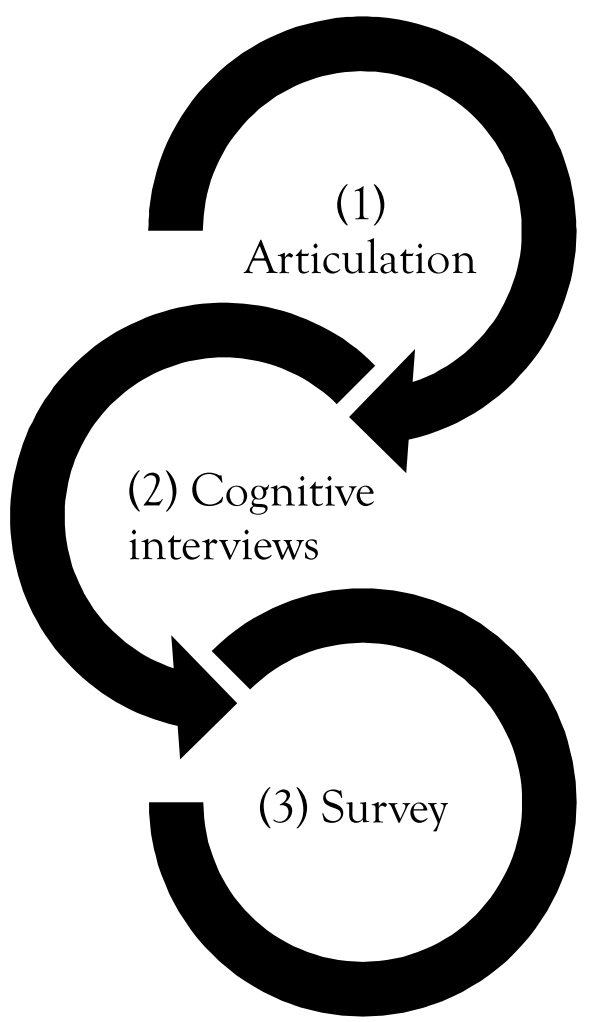

Figure 1: Representing the Triangulation methodology to Address the Study's Research Question

In this research, primarily the articulation approach has been used to identify the constraints from the existing literature. The following established literature in the Table 1 is reviewed and key arguments from it are picked in this section.

Followed by articulation, as most of the constraints identified in articulation stage were from the university education perspective (as there was a lack of literature on professional accounting institutes) therefore, 3 cognitive interviews (semi-structured) have been conducted to identify constraints from the academicians (expert sampling) 
Table 1: Representing Literature that is Reviewed and Key Arguments From it are Used within Articulation

\begin{tabular}{|c|c|c|c|}
\hline S. N & Author/Date & Articles/Books/thesis & Publisher \\
\hline 1 & $\begin{array}{l}\text { Bui, B., \& Porter, B. } \\
\text { (2010) }\end{array}$ & $\begin{array}{c}\text { The expectation-performance gap in } \\
\text { accounting education: An exploratory } \\
\text { study }\end{array}$ & $\begin{array}{l}\text { Accounting Educa- } \\
\text { tion: An International } \\
\text { Journal }\end{array}$ \\
\hline 2 & Millard, P. (2003) & Promoting the profession & $\begin{array}{l}\text { Chartered Accoun- } \\
\text { tant Journal of New } \\
\text { Zealand }\end{array}$ \\
\hline 3 & $\begin{array}{l}\text { Adams, S., Pryor, L., \& } \\
\text { Adams, S. (1994) }\end{array}$ & $\begin{array}{l}\text { Attraction and retention of high-ap- } \\
\text { titude students in accounting: An } \\
\text { exploratory longitudinal study }\end{array}$ & $\begin{array}{l}\text { Issues in Accounting } \\
\text { Education }\end{array}$ \\
\hline 4 & $\begin{array}{l}\text { Kavanagh, M., \& Dren- } \\
\text { nan, L. (2007) }\end{array}$ & $\begin{array}{l}\text { Graduate attributes and skills: Are we } \\
\text { as accounting academics delivering the } \\
\text { goods? }\end{array}$ & $\begin{array}{c}\text { Accounting and } \\
\text { Finance Association } \\
\text { of Australia and New } \\
\text { Zealand }\end{array}$ \\
\hline 5 & $\begin{array}{l}\text { Hassall, T., Joyce, J., } \\
\text { Montaño, J. L. A., \& } \\
\text { Anes, J. A. D. (2005) }\end{array}$ & $\begin{array}{l}\text { Priorities for the development of voca- } \\
\text { tional skills in management accoun- } \\
\text { tants: A European perspective }\end{array}$ & Accounting Forum \\
\hline 6 & $\begin{array}{l}\text { Milner, M. M., \& Hill, } \\
\text { W.Y. (2008) }\end{array}$ & Examining the skills debate in Scotland & $\begin{array}{l}\text { International Journal } \\
\text { of Management Edu- } \\
\text { cation }\end{array}$ \\
\hline 7 & $\begin{array}{l}\text { Murdoch, B., \& Guy, } \\
\text { P.W. (2002) }\end{array}$ & $\begin{array}{c}\text { Active learning in small and large } \\
\text { classes }\end{array}$ & Accounting Education \\
\hline 8 & $\begin{array}{l}\text { Craig, R., \& Amernic, } \\
\text { J. (2001) }\end{array}$ & $\begin{array}{l}\text { Accountability of accounting educators } \\
\text { and the rhythm of the universities: } \\
\text { resistance strategies for post-modern } \\
\text { blues }\end{array}$ & $\begin{array}{l}\text { Accounting Educa- } \\
\text { tion: an international } \\
\text { journal }\end{array}$ \\
\hline 9 & Haigh, N. (1994) & $\begin{array}{l}\text { Promoting intellectual independence: a } \\
\text { legislative catalyst }\end{array}$ & $\begin{array}{l}\text { Higher Education } \\
\text { Research and Devel- } \\
\text { opment Society of } \\
\text { Australasia }\end{array}$ \\
\hline 10 & $\begin{array}{c}\text { Dominelli, L., \& } \\
\text { Hoogvelt, A. (1996) }\end{array}$ & $\begin{array}{l}\text { Globalisation, the privatisation of } \\
\text { welfare, and the changing role of profes- } \\
\text { sional academics in Britain }\end{array}$ & $\begin{array}{l}\text { Critical perspectives } \\
\text { on Accounting }\end{array}$ \\
\hline 11 & Seldin, P. (1995) & Improving college teaching & Anker Publishing Co \\
\hline 12 & $\begin{array}{l}\text { Porter, B. A., \& Carr, } \\
\text { S.A. (1999) }\end{array}$ & $\begin{array}{l}\text { From Strategic Plan to Practical Real- } \\
\text { ities: Developing and Implementing a } \\
\text { Zero@Based Accounting Curriculum }\end{array}$ & $\begin{array}{l}\text { Issues in Accounting } \\
\text { Education }\end{array}$ \\
\hline
\end{tabular}


teaching in professional accounting institutes of Pakistan. There were two reasons for conducting the semi-structured interviews; first, it allows the interviewer to prepare questions well in advance considering the investigated phenomenon and second, it allows to check the qualitative data reliability by comparing the participants' views on a similar set of questions.

In order to investigate the phenomenon under investigation, three questions were asked of the interviewed participants:

Q1: What skills do you think accounting students should acquire for the career development of their accounting profession?

Q2: What factors do you think are limiting your ability towards skills development in your students?

Q3: How does the identified constraining factors are affecting your ability towards skills development in your students?

The Question 1 was asked to comprehend the understanding of the term 'skills' in participants mind, ensuring the right selection of the expert participants. Question 2 and Question 3 were two specific questions that were designed to explore the constraining elements and how they affect the ability of academics in the development of skills in their students.

The profiles of the interviewed participants are: -

a. Participant 1: involve in teaching activities, coordinating different accounting courses at one of the prestigious accounting institute. Further, he has more than 4 years of practitioners' experience in different professional organisations in Pakistan.

b. Participant 2: involved in teaching and managing administrative functions for more than 5 years in one of the prestigious accounting institute in Pakistan. Additionally, he has more than 3 years of practitioners' experience.

c. Participant 3: is a principal of one of the leading accounting institute. Further, he is involved in teaching and managing administrative activities of the institute and has more than 4 years of practitioners' experience.

Finally, a descriptive survey has been conducted across professional accounting institutes of Pakistan to identify prevailing constraints. In Pakistan, there are five active accounting bodies having 37 registered education centres across the country to provide professional accounting education, that are, the Institute of Chartered Ac- 
countants of Pakistan (ICAP), the Institute of Cost and Management Accountants of Pakistan (ICMAP), the Institute of Certified Public Accountants of Pakistan (ICAP), the Society of Accounting Education (SOAE) and the Pakistan Institute of Public Finance Accountants (PIPFA) (Parvaiz et al., 2017). Unfortunately, unlike developed countries, in Pakistan there is no database available, providing information regarding number of educators working in accounting educational institutes (For example, in New Zealand - Wiley Directory of Accounting provides information about all available accounting academics). Therefore, data in this research were collected by using a non-probability sampling technique that is snowball sampling, which impose no restriction on knowing the exact population size. In total, 460 questionnaires were distributed among educators of the professional accounting institutes in Pakistan (See Appendix 2). In response, 201 usable questionnaires were returned which were good enough for descriptive analysis. In this regard see Table 2 representing demographic details (gender, age, work experience, position, professional education and general academic qualification) from the respondent group.

Table 2: Representing the Demographic Details of the Respondents (Educators)

\begin{tabular}{|c|c|c|}
\hline Demographic & Category & Educators group \\
\hline \multirow{4}{*}{ Gender } & Male & $188(93.5 \%)$ \\
\hline \multirow{4}{*}{ Age } & Female & $13(6.5 \%)$ \\
\hline \multirow{5}{*}{ Experience } & $20-24$ years & $3(1.5 \%)$ \\
\cline { 2 - 3 } & $25-35$ years & $141(70.1 \%)$ \\
\cline { 2 - 3 } & $36-44$ years & $52(25.9 \%)$ \\
\cline { 2 - 3 } & $45-54$ years & $5(2.5 \%)$ \\
\hline \multirow{5}{*}{} & 55 - above & - \\
\cline { 2 - 3 } & Less than a year & $2(1 \%)$ \\
\cline { 2 - 3 } & $1-3$ years & $131(65.2 \%)$ \\
\cline { 2 - 3 } & $4-7$ years & $44(21.9 \%)$ \\
\cline { 2 - 3 } & $8-10$ years & $19(9.5 \%)$ \\
\hline \multirow{5}{*}{ Position } & 11 years and more & $5(2.5 \%)$ \\
\hline \multirow{5}{*}{} & Top level executive & $\mathrm{N} / \mathrm{A}$ \\
\cline { 2 - 3 } & Middle level executive & $\mathrm{N} / \mathrm{A}$ \\
\cline { 2 - 3 } & Others & $\mathrm{N} / \mathrm{A}$ \\
\cline { 2 - 3 } & Full time academic & $57(28.4 \%)$ \\
\cline { 2 - 3 } & Part time academic & $144(71.6 \%)$ \\
\hline
\end{tabular}




\begin{tabular}{|c|c|c|}
\hline \multirow{2}{*}{$\begin{array}{c}\text { Participants who had Profes- } \\
\text { sional accounting education }\end{array}$} & Yes & $35(17.4 \%)$ \\
\cline { 2 - 3 } General academic qualification & No & $166(82.5 \%)$ \\
\cline { 2 - 3 } & $\begin{array}{c}\text { Higher Secondary School } \\
\text { Certificate }\end{array}$ & $16(8 \%)$ \\
\cline { 2 - 3 } & Bachelor degree & $91(45.3 \%)$ \\
\cline { 2 - 3 } & Master degree & $64(31.8 \%)$ \\
\cline { 2 - 3 } & Masters of Philosophy & $30(14.9 \%)$ \\
\hline
\end{tabular}

\section{Analysis and Results}

\subsection{Articulation}

In consideration of prior literature this section identifies the numerous constraining elements from an academic community perspective. The Justification for each of the identified constraining elements along with their references are discussed below: -

Bui and Porter (2010) assert that student related factors such as their intellectual ability and attitude towards the accounting profession and accounting education limits the educators' ability to develop skills in students. For-example, Millard (2003) states that students characterize the accounting profession as dull and the work laborious and accountants as mere bean counters. Such shared perceptions are alarming for the stability of a sound academic discipline and discourages students with higher intelligence to opt for a career in accounting. This aspect is evident through the declining rate of students' enrolment in the accounting discipline. For example, Adams et al. (1994) conducted a longitudinal study and found that students leaving accounting programs are generally those who have higher grade point average (GPA) scores than those who did not. Further, this situation affects the institutional quality audits and leads to compromises on students' intake criteria (Bui \& Porter, 2010). This, in turn, leads to classes that have students with substandard academic qualifications and a misappropriated attitude towards learning. This aspect is well-evidenced through the following statements: -

"Students enrolling in accounting classes today don't have the basic skills needed to learn at a fast enough pace" (Kavanagh \& Drennan, 2007, p. 30)

And...

"From comments expressed by the case study interviewees, it seems that, broadly speaking, accounting students' attitude towards learning is not satisfactory" (Bui \& Porter, 2010, p. 42) 
Considering the above discussion, the following two elements were identified as constraining elements:

1. Students enrolling in accounting classes do not have adequate academic skills to learn at a fast pace

\section{Students have an inappropriate attitude towards learning of Professional accounting education}

Other constraints are found to be originating from the institutional environment that contribute to limiting the educators' abilities to inculcate skills in students. In this regard, the foremost element identified as 'student-to-lecturer ratios'. Bui and Porter (2010) asserted that universities have not been able to employ lecturing staff commensurate with the number of students' due to financial reasons. In this regard, they argued the following, as stated by one of their interviewees:-

"Accounting is the milk cow of universities. Accounting has always been a single major that attracts the most students of all the degrees offered at this university. The need for [university] revenues leads to big [accounting] classes, which in turn hinders teaching quality." (Bui \& Porter, 2010, p. 39)

This phenomenon was also noticed by Hassall et al. (2005) and later by Milner and Hill (2008). For-example, Milner and Hill (2008) quoted from one academic he interviewed as: -

"Our classes are double the size than they were ten years ago. Um, probably students coming in who are less motivated now towards a degree education [interview 30]" (p. 21)

Murdoch and Guy (2002) investigated the students' performance based on class size. They reported that students who had been taught in small classes appeared to show better signs of academic achievement than students from large classes. Craig and Amernic (2001) found an audit culture that focused on quantity and revenue, that is, one based on the number of students in order to collect a large amount of revenue. The implication was that teaching quality standards were compromised due to that priority. Thus, the next constraining element is identified as:

\section{Classes are packed with a large number of students}

Haigh (1994) found that accounting students expected academicians to teach knowledge and skills in education which are applicable to their immediate working environment. And if an educator, deviates from this goal, then students showed a negative attitude towards them. This issue was reported by Bui and Porter (2010) from 
one of his interviewee's (academic) perspective as: -

"We used to require students to take liberal papers to [final year] level as part of the BCA requirements .... However, the students did not like this. They voted to get rid of this requirement. They wanted to learn only things that [they think] are directly relevant, or at least as close as possible to their major." (p. 40)

Hence, if accounting students have to be professionally credible, then the accounting curriculum should have enough provisions to incorporate the knowledge of those subjects that allow for the development of skills in students.

The next constraining element refers to:

\section{Accounting curriculum has an insufficient provision to allow for the effective development of skills}

Dominelli and Hoogvelt (1996) argues that:

"Letting outside bodies set the research agenda has squeezed the funding of scholarly research which underpins teaching, thereby jeopardizing the quality of teaching." (p. 205)

In the above statement Dominelli and Hoogvelt (1996) explicitly direct attention towards an increasing emphasis on research activities in academia. This phenomenon was also noticed by Bui and Porter (2010), stated:

"By contrast, teaching excellence attracts relatively little recognition. Two of the educator interviewees expressed concern about the differential reputational effect of excellence in teaching and research, with the possible effect of teaching has become viewed by academics as a burden. Three other interviewees noted that they have a genuine interest in teaching but the combined effect of the university's reward system and the difficulty of simultaneously satisfying all of their academics' responsibilities results in their according highest priority for research." (p. 41)

Hence, considering this, the next constraining element to include in the component of institutional constraint is identified as: -

\section{As the institutes shift to research based culture, educators are too busy with research that this impacts their teaching abilities negatively}

Finally, a constraining element to teaching practice is 'inadequate reward system' as highlighted by Seldin (1995): -

"Many teachers argue that the biggest roadblock to improved teaching is the 
reward system that pits teaching against research. Many institutions give lip service to the importance of teaching, but then turn around and reward scholarly research and publication." (p. 6)

Later, work by Porter and Carr (1999), Kavanagh and Drennan (2007) and Bui and Porter (2010) also highlighted this issue and signified the importance of having a proper rewards system to enhance teaching excellence. In this regard, Bui and Porter (2010) stated that many educators have a genuine interest in teaching but due to a rewards system linked to research they are inhibited from achieving excellence in teaching practices. Bui and Porter (2010) state:

“The university's promotion and tenure policy also operate to hinder improvements in accounting education in the case study programme. As four of the educators interviewees observed, although academics have research, teaching and administrative responsibilities, research productivity is the key factor in promotion and tenure decisions - and its supremacy has been heightened in recent years as a result of the introduction of performance based funding (PBRF) by the NZ Government. By contrast, teaching excellence attracts relatively little recognition.” (p. 41)

As such, the final constraining element is:

\section{Institutions do not reward high quality teaching practices}

In summary, through prior studies, six constraining elements have been identified which are listed in Table 3 with source literature.

Table 3: Selected Constraining Elements to be Included in the Questionnaire from Prior Studies

\begin{tabular}{|c|c|c|}
\hline & Constraining elements & Literature source \\
\hline 1. & $\begin{array}{l}\text { Students enrolling in accounting classes do not have ade- } \\
\text { quate academic skills to learn at a fast pace. }\end{array}$ & Kavanagh and Drennan (2007) \\
\hline 2. & $\begin{array}{c}\text { Students have an inappropriate attitude towards learning } \\
\text { of professional accounting education. }\end{array}$ & Bui and Porter (2010) \\
\hline 3. & Classes are packed with a large number of students. & $\begin{array}{l}\text { Milner and Hill (2008) } \\
\text { Murdoch and Guy (2002) Has- } \\
\text { sall et al. (2005) }\end{array}$ \\
\hline 4. & $\begin{array}{l}\text { Accounting curriculum has an insufficient provision to } \\
\text { allow for the effective development of skills. }\end{array}$ & $\begin{array}{c}\text { Haigh (1994) } \\
\text { Bui and Porter (2010) }\end{array}$ \\
\hline 5. & $\begin{array}{l}\text { As the institutes shift to research based culture, educators } \\
\text { are too busy with research that this impacts their teaching } \\
\text { abilities negatively. }\end{array}$ & Dominelli and Hoogvelt (1996) \\
\hline 6. & Institutions do not reward high quality teaching practices. & $\begin{array}{l}\text { Seldin (1995) Bui \& Porter, } \\
2010 \text { Porter and Carr (1999) }\end{array}$ \\
\hline
\end{tabular}




\subsection{Cognitive interviews of experts}

For cognitive interviews, initially participant responses were recorded and later transcribed for textual analysis. During the interview process, academicians have identified seven constraining elements. The discussion on each of the identified constraining elements (numbered 1 to 7 ) along with their transcripts are given below: -

1) Students attitude towards learning:

From the educators' perspective, the first constraining element towards a skills development process is identified as 'students' non-serious attitude for learning education'. In this regard participant 2 stated that most of the accounting students have an attitude problem, specifically, when they attend classes, they come with sleepy or tired eyes and they take education as an extra burden on themselves. They are unaware of the importance of education. And in that regard, one of the major contributions is from their traditional home environment. Specifically, they are not guided by their parents on how to take responsibility for their education. They consider learning as a secondary thing. And because of this, teachers have to waste most of their time on disciplinary activities to maintain the decorum of the class and to make everyone attentive, rather than emphasising learning activities. In this regard one participant's comment is pertinent:

"...students do have the attitude problem, they play with iphone, there mood is inappropriate in the class room. Just for instance at that day I have asked a one [students] in the classroom, he was rubbing his eyes so I told him what's the problem? Are you ok? [Student replied] sir, I am fine, I am ok. Then I asked why are you sitting like that? So he replied, sir, I was awake till 3 o'clock. Then I asked why you were awake till 3 o'clock? He [student] replied sir, I was watching a movie. Then I said it's fine that is not a bad thing, but you have to be responsible for the things that you have to do tomorrow. [12]" [Participant 2]

Thus, the following constraining statement is derived to represent the recorded constraint:

Students do not have a serious attitude for learning

2) Interest in the accounting discipline:

From the educators' perspective, the second constraining element towards skills development process is identified as 'students' lack of interest in the accounting discipline'. In this regard participant 1 stated that accounting education in Pakistan is considered as a last option. Most of the students have intentions to take admission in engineering or medical colleges. But when they fail to qualify for admission they 
enrolled in accounting institutes. He stated: -

"... unfortunately here accounting is considered as a last option. Students when get drop from the entry test exams of engineering or medical colleges or they don't qualify to get admissions in universities then they come towards accounting institutes [9]" [Participant 1]

Speculatively, most of the students in the accounting institutes are those who are studying accounting because they failed to qualify for their desired disciplines. Seemingly, as they do not have an interest in accounting, they are less inclined to take the responsibility to continue with it:

“... I think there is a need to work on students' aptitude [7]” [Participant 1]

"... If they [students] don't come to have interest in it then they will move to other courses or leave. For us we want students to come here who have really interest in it [10]" [Participant 1]

Speculatively, this could be one of the reasons for the high drop-out ratio in accounting education in Pakistan. Thus, the following constraining statement is determined:

Students have a lack of interest in the accounting discipline

3) Perception of accounting education:

Another constraining element in the skills development process is 'students' misperception about accounting education'. In this regard participant 1 stated that there is a misperception among most of the students. That is, to be an accountant one must be competent in mathematics. Consider, for example, the following comments:

"As for related to accounting there is a misconception, misperception about accounting discipline. People [students] think that to be accountant you have to be very competent in mathematical skills. This differentiation is needed to be clear about accounting and mathematics [6]" [Participant 1]

"Students have no idea what is accounting. They have not studied [8]" [Participant 1]

One can therefore speculate that some intelligent, non-mathematically gifted students might be reluctant to obtain admission in an accounting program. And perhaps consequently, the job of accounting academics becomes more difficult if the pool of students is of a lower academic standard. Arguably, one may determine the following constraint: 
People (potential students) have a misperception about accounting education as being highly mathematical in nature

4) Training opportunities for academics:

From an accounting educators' perspective, the fourth constraining element, hindering the skills development process is identified as 'inadequate training opportunities for accounting academics'. In this regard, one of the participants stated that the teaching methodologies used are quite old fashioned. For example:

"... our teaching methodologies should have some change. Because the problem of a generation gap is started here. Teachers are quite old and students are new [young] [11]" [Participant 2]

And...

"But I think teaching methodologies should be more modern as well because we also have to give some gap to children. You can't treat people like the way we used to treat them in old times. Then we used to criticize in old times as well that teachers were quite strict on us. But nowadays it's a bit difficult to do like that [13]" [Participant 2]

Thus, the following constraining statement is recorded as a constraint:

Accounting institutes are not offering adequate training opportunities to their academic staff

5) Training organisations and standard procedures:

The fifth constraining element of the skills development process is identified as 'training organisations are not following standard procedures to develop skills in trainees'. In Pakistan, all the registered training organisations are required by the accounting bodies to follow particular directions (skills development matrix) while developing skills in accounting students. These directions explicitly state the percentage of time to be spent in each area of skills development during training (job contract/ job placement/articleship), for example, $15 \%$ of time in the audit section, $10 \%$ of time in statutory filing, $5 \%$ of time in book-keeping etc. Unfortunately, compliance by the training organisations is rare in that most of the students remain untrained in many of the valuable skills which they are meant to possess. For example:

"Another problem is from the perspective of training organisations. Over here good training organisations quantity is much lower. So for them it is a little hard to take more intake of students. So rest of the students either wait in the pipeline or they have to go here and there. So they can't learn what is 
expected of them like leadership and analytical skills which you are talking about. One goes to the government or some small private institution for-example XY\& Co. There he will come to learn ledger entries and book keeping [14] ...So there is no standard criteria for measuring skills level to students in articleship. We have to believe on training organisation. That is why when students from average or below average firms goes to employment, then these things they have to face in the interviews [15]" [Participant 2]

Thus the following constraining statement is derived to represent the recorded constraint as:-

Some of the training organisations are not following the standard procedures to develop skills in students as suggested by the accounting bodies

6) Finding Competent teaching staff:

The sixth constraining element in the skills development process is identified as 'accounting institutes having difficulty in finding competent teaching staff. In this regard, one of the participants stated that most of the accounting institutes are small setups where they lack opportunities for academics to grow professionally. As such, academicians tend not to see their professional career in accounting institutes. Therefore, they prefer to teach in universities due to their taller professional organisational hierarchy (that is, lecturer, assistant professor, associate professor, professor), where they can find promotional opportunities. Arguably, it is often because of this reason that the accounting institutes have difficulty in finding competent teaching staff. By extension the students' skill development process also suffers. In this regard participant 3 stated:

“... we are not being able to retain good teaching staff members. Most of the individuals who work here as teachers prefer to be as part timers rather than full time basis... Because here our academic setup is institutional, we don't have a big organisational hierarchy here. Therefore, he [teacher] can't see his career in it [10]" [Participant 3]

Thus, the following constraining statement is determined:

Accounting institutes find it difficult to find competent academic staff

7) Stipend rates during articleship:

The seventh constraining element in the skills development process is identified as 'inadequate stipend offered by training organisations'. During training (job contract/job placement/articleship), professional organisations tend to offer a very low 
stipend of Rs. 8000 per month to trainees. Since this training period is three and a half years long, during this period, it becomes difficult for the trainees to survive on this stipend. The stipend amount is not enough to meet their monthly expenses for travel and food. Consequently, most of the students leave their accountancy programs in the middle of their training and join some professional organisations to support their families as partly qualified accountants. In this regard participant 3 stated:

"Another problem is financial incentives. If you don't give good enough incentives, then their [students'] performance gets effected. The problem accounting students do face when they go to training organisation firms is that they have set stipend. Looking at the inflation factor in our country, the amount of money, which they are getting they can't fulfil their daily expenses, even not their travelling which is a very much big constraint [11]... So I think it is a very big constraint I mean Rs. 8000/- is nothing nowadays [12]" [Participant 3]

Thus, the following constraining statement is derived to represent the recorded constraint:

During their articleships, students' get de-motivated due to inadequate stipend offered by most of the training organisations

In summary, during cognitive interviews, academic participants have identified seven constraining elements, which are listed in Table 4 below.

Table 4: Enlisting 7 Constraining Elements that were Identified from the Participants' Data

\begin{tabular}{|c|c|}
\hline & Constraining elements \\
\hline 1 & Students do not have a serious attitude for learning \\
\hline 2 & Students have a lack of interest in the accounting discipline \\
\hline 3 & $\begin{array}{c}\text { People (potential students) have a misperception about accounting education as being } \\
\text { highly mathematical in nature }\end{array}$ \\
\hline 4 & $\begin{array}{c}\text { Accounting institutes are not offering adequate training opportunities to their academic } \\
\text { staff }\end{array}$ \\
\hline 5 & $\begin{array}{c}\text { Some of the training organisations are not following the standard procedures to develop } \\
\text { skills in students as suggested by the accounting bodies }\end{array}$ \\
\hline 6 & Accounting institutes find it difficult to find competent academic staff \\
\hline 7 & $\begin{array}{c}\text { During their articleship, students' get de-motivated due to inadequate stipend offered by } \\
\text { most of the training organisations }\end{array}$ \\
\hline
\end{tabular}




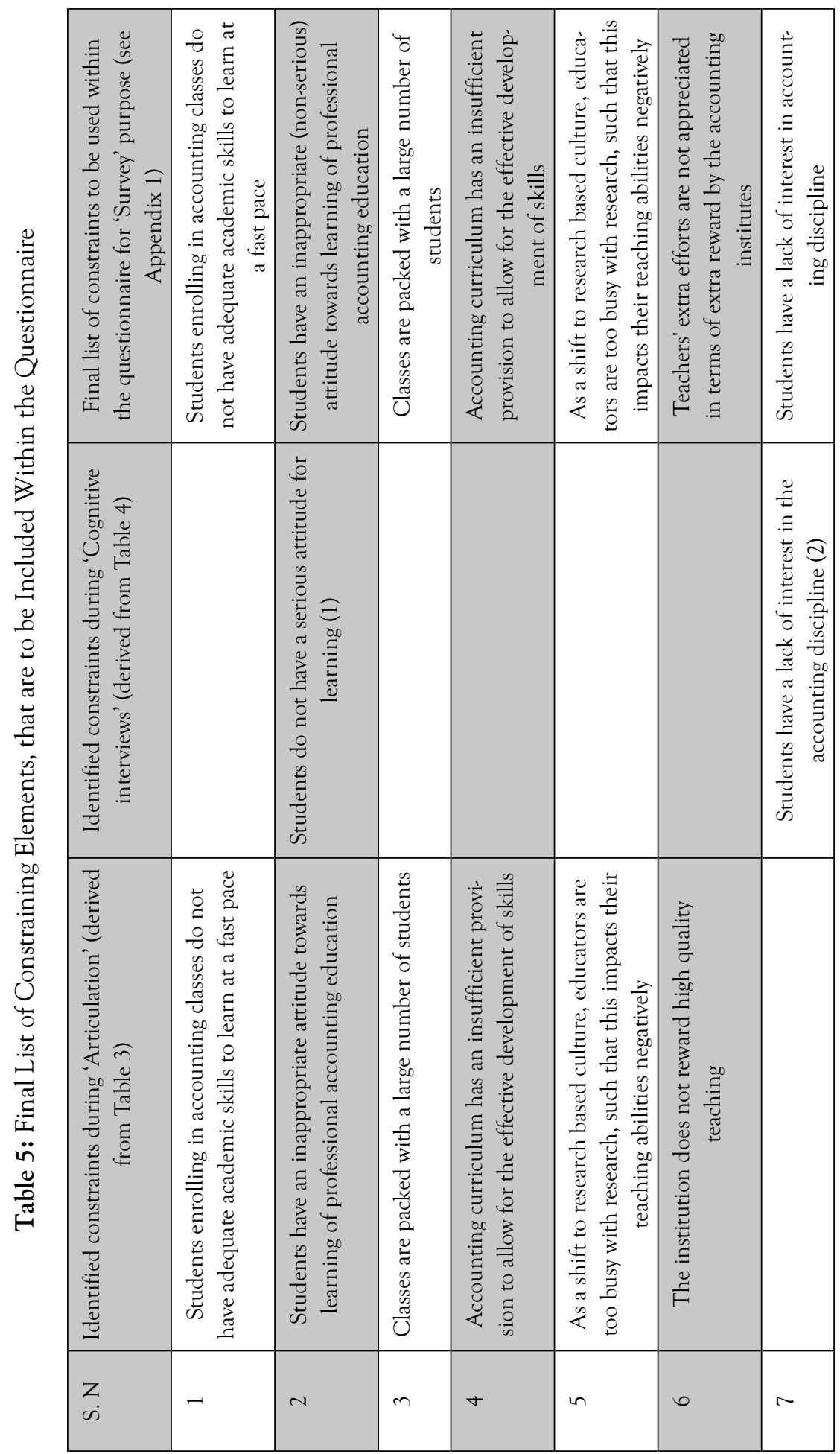




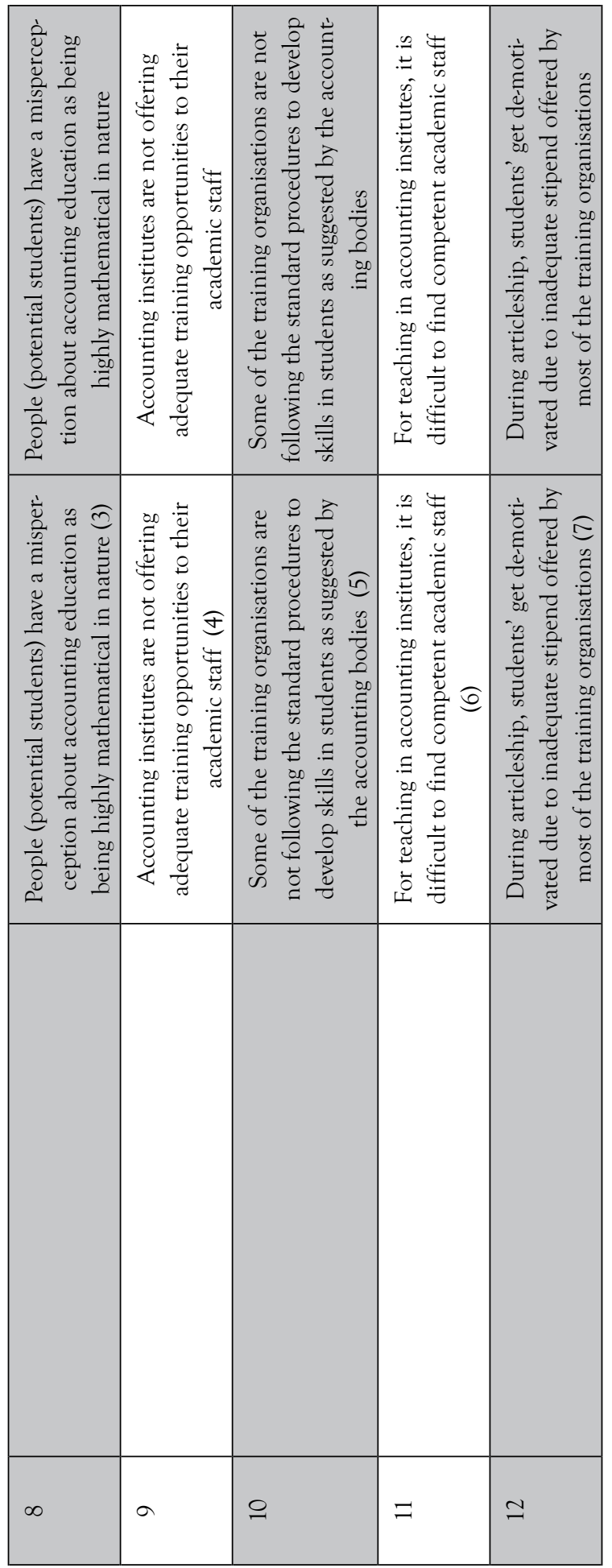


In short, the accumulated findings from the articulation (Table 3) and cognitive interviews (Table 4) are summarised in Table 5; identifying a final list of constraints to be used in the questionnaire for surveying purpose (see Appendix 1).

\subsection{Survey}

This section reports the findings from the surveyed questionnaire. The aim here was to identify the constraining elements which prevail within the professional accounting education system of Pakistan.

In order to know which constraining elements prevailed, the statistical mean (the central tendency of the data) for each of the constraining elements was calculated. From Table 6, it can be seen that the values of the statistical mean are in the range of 1.78 to 4.01 . In interpreting these results, the constraining elements having a mean value of more than 3 would fall within the category of a valid constraint within the accounting education system of Pakistan. This is because any value greater than ' 3 ' represents the data's skews towards 'strongly agree/agree' side of the response option continuum. Thus, any value greater than 3 indicates the overall respondents' agreement towards the existence of the constraint. But to enhance the level of confidence an additional measure was considered, that is, the percentage of respondents who have given the 'agreement' score. The percentage agreement score over the constraining elements was found to be in the range of $3.5 \%$ to $71.1 \%$. Hence, in interpreting the findings from Table 6 , the constraining elements having a mean score greater than 3 and a percentage agreement score more than 50 were considered to prevail within the professional accounting education system.

The findings from the surveyed questionnaires were categorised in Table 6 and placed into two categories: Category 1 (Prevailed) and Category 2 (Rejected): -

Category 1 - Prevailed: representing those elements (6 constraints), where the majority of the educators $(>50 \%)$ agreed constrain the ability of accounting educators to effectively develop skills in students. Such constraints include training organisations are not following standard procedure to develop skills in students, people (potential students) have misperceptions about accounting education, enrolling students in accounting classes have inadequate academic skills, inadequate stipends offered by training organisations, accounting institutes are not appreciating teaching activities, and lack of training opportunities for academics.

Category 2 - Rejected: representing those elements (6 constraints), where a majority of educators $(>50 \%)$ does not agree that such elements constrain the ability 
Table 6: Representing the Categorisation of Constraining Elements, Considering the Results of Statistical Mean and Percentage Agreement Score.

\begin{tabular}{|c|c|c|c|}
\hline S. N & Category 1 - Prevailed & $\begin{array}{l}\text { Mean values with Per- } \\
\text { centage of agreement } \\
\text { score in parenthesis }\end{array}$ & $\begin{array}{l}\text { Constraints } \\
\text { status }\end{array}$ \\
\hline 1 & $\begin{array}{l}\text { Some of the training organisations are not } \\
\text { following the standard procedures to develop } \\
\text { skills in students as suggested by the account- } \\
\text { ing bodies }\end{array}$ & $4.01(71.1 \%)$ & Prevailed \\
\hline 2 & $\begin{array}{c}\text { Teachers' extra efforts are not appreciated } \\
\text { in terms of extra reward by the accounting } \\
\text { institutes }\end{array}$ & $3.92(54.7 \%)$ & Prevailed \\
\hline 3 & $\begin{array}{c}\text { People (potential students) have a mispercep- } \\
\text { tion about accounting education as being } \\
\text { highly mathematical in nature }\end{array}$ & $3.75(58.7 \%)$ & Prevailed \\
\hline 4 & $\begin{array}{l}\text { Students enrolling in accounting classes do } \\
\text { not have adequate academic skills to learn at } \\
\text { a fast pace }\end{array}$ & $3.76(54.8 \%)$ & Prevailed \\
\hline 5 & $\begin{array}{l}\text { During articleship, students' get de-motivated } \\
\text { due to inadequate stipend offered by most of } \\
\text { the training organisations }\end{array}$ & $3.69(55.7 \%)$ & Prevailed \\
\hline 6 & $\begin{array}{l}\text { Accounting institutes are not offering ade- } \\
\text { quate training opportunities to their academic } \\
\text { staff }\end{array}$ & $3.42(57.7 \%)$ & Prevailed \\
\hline S. N & Category 2 - Rejected & $\begin{array}{l}\text { Mean values with Per- } \\
\text { centage of agreement } \\
\text { score in parenthesis }\end{array}$ & $\begin{array}{l}\text { Constraints } \\
\text { status }\end{array}$ \\
\hline 1 & $\begin{array}{l}\text { For teaching in accounting institutes, it is } \\
\text { difficult to find competent academic staff }\end{array}$ & $1.87(6 \%)$ & Rejected \\
\hline 2 & $\begin{array}{c}\text { Students have an inappropriate (non-serious) } \\
\text { attitude towards learning of professional } \\
\text { accounting education }\end{array}$ & $2.27(7 \%)$ & Rejected \\
\hline 3 & $\begin{array}{l}\text { Classes are packed with a large number of } \\
\text { students }\end{array}$ & $1.98(7.5 \%)$ & Rejected \\
\hline 4 & $\begin{array}{l}\text { Accounting curriculum has an insufficient } \\
\text { provision to allow for the effective develop- } \\
\text { ment of generic skills }\end{array}$ & 2.07 (13.9\%) & Rejected \\
\hline 5 & $\begin{array}{l}\text { As a shift to research based culture, educators } \\
\text { are too busy with research, such that this } \\
\text { impacts their teaching abilities negatively }\end{array}$ & $1.78(3.5 \%)$ & Rejected \\
\hline 6 & $\begin{array}{l}\text { Students have a lack of interest in the ac- } \\
\text { counting discipline }\end{array}$ & $2.55(15.9 \%)$ & Rejected \\
\hline
\end{tabular}


of accounting educators to effectively develop skills in students. Such constraints include, difficult to find competent academic staff, students' non-serious attitude to learning, too many students in a class, curriculum has no provision to develop skills effectively in students, research based culture, and students' lack of interest in the accounting discipline.

\section{Conclusion}

Previously, Kavanagh and Drennan (2007) investigated the constraining elements from a university education perspective in Australia. In their research, the prevailing constraints included: academicians not having time to involve accounting practitioners in curriculum development, lack of financial resources to align the interface between practice and education, inadequate reward for effective teaching practices, academicians are far too occupied with research to keep their curriculum updated, and academic research supporting course content that is often not recognised by accounting practitioners. Similarly, Bui and Porter (2010) also identified constraining elements from a New-Zealand university context, that included: conflict between teaching and research, class size, and the shift of funding structure from teaching into a research based culture. However, contrastingly this research identifies the constraining elements of the professional accounting institutes rather than the university. The prevailing constraints within the accounting education system of professional accounting institutes are listed in Category 1 -Prevailed (see Table 6). Most of the constraining elements that were earlier found in the literature to prevail in the university education system were rejected from professional accounting institutes in Pakistan. Such constraining elements include conflict between teaching and research, class size and academicians' preoccupation with research (see Category 2 - Rejected in Table 6). In this research, within the category of "prevailing constraints", the first and fifth identified constraining elements are related to training organisations (see Category 1 - Prevailed in Table 6). Most of the academics (71.1\%) believe that the training organisations are not training their trainees to the standard suggested by the accounting bodies. Due to this some of the accounting students remain behind in skills development. Additionally, the majority of the academics (55.7\%) also believed that the monthly stipend (Rs. 8000/-) offered to accounting students are inadequate during the work placement (articleship) and a key reason for students' de-motivation. Further, academicians believed that students' de-motivation was one of the barriers to the effective development of skills in students. The second and sixth prevailing constraints are related to academic accounting institutes (see Category 1 - Prevailed in Table 6). Almost $54.7 \%$ of the academics believed that their teaching efforts were not appreciated by the accounting institutes in terms of reward. In such a situation, accounting academicians feel demoralized. Thus, they do no exert any extra effort 
to develop student skills. Other than that, the majority $(57.7 \%)$ also believed that accounting institutions were not offering adequate training opportunities to their academic staff for the development of their teaching abilities. Arguably, this lack of training makes accounting academics ineffective in the development of skills in students, up to the desired competence level expected by employers. The third prevailing constraining element is related to students' misperception about the nature of accounting education (see Category 1 - Prevailed in Table 6). About 58.7\% of the academics believed that most of the individuals in Pakistan have a misperception about accounting education as being mathematical in nature. And, due to this reason, most of the brilliant students who have the right aptitude to be accountants are reluctant to opt for it. Resulting accounting institutions remain with few numbers of individuals, having a weak academic background to enroll. This argument is evidenced by the fourth constraining element, where the majority of the academics (54.8\%) has asserted that most of the enrolling students' in accounting institutes were academically below the level of adequate standards (see Category 1 - Prevailed in Table 6).

This research brings a new theoretical perspective on constraints from the professional accounting institutes. Professional accounting institutes are quite different to the universities where most of the earlier research regarding constraints in academia has been conducted. These differences relate to teaching methodology, funding structure, employment policy, reward system, curriculum development, examination systems, and students' intake criteria. Therefore, these differences suggest the possibility of a different set of constraints. Similarly, it is also true to argue that, the previously identified constraints from the university education perspective are not valid from the perspective of professional accounting institutes, at least, without having any prior evidence for their relevance. Therefore, this study has made an attempt to identify the constraining elements that are prevailing within the professional accounting institutes of Pakistan.

To date, the exact population size of academics teaching in professional accounting institutes of Pakistan is unknown. Therefore, for future research, a detailed survey is recommended to test the generalisability of this research findings by employing simple random sampling technique (probability sampling technique) after knowing the exact population size.

\section{References}

Adams, S., Pryor, L. \& Adams, S. (1994). Attraction and retention of high-aptitude students in accounting: An exploratory longitudinal study. Issues in Accounting Education, 9(1), 45-58.

Arthur Andersen \& Co., Arthur Young, Coppers \& Lybrand, Deloitte, Haskins \& Sells, Ernst \& 
Whinney, Peat Marwick Main \& Co., Price Waterhouse and Touche' Ross. (1998). Perspectives on Education: Capabilities for Success in the Accounting Profession (The White Paper).

Bui, B., \& Porter, B. (2010). The expectation-performance gap in accounting education: An exploratory study. Accounting Education: An International Journal, 19(1-2), 23-50.

Craig, R., \& Amernic, J. (2001). Accountability of accounting educators and the rhythm of the universities: Resistance strategies for post-modern blues. Accounting Education: An International Journal, 11(2), 121-171.

De-Lange, P., Jackling, B., \& Gut, A. M. (2006). Accounting graduates' perceptions of skills emphasis in undergraduate courses: an investigation from two Victorian universities. Accounting $\mathcal{E}$ Finance, 46(3), 365-386.

Dominelli, L., \& Hoogvelt, A. (1996). Globalisation, the privatisation of welfare, and the changing role of professional academics in Britain. Critical Perspectives on Accounting, 7(1), 191-212.

Duncan, J., \& Schmutte, J. (2006). Change in accounting programs: The impact of influences and constraints. The Accounting Educators' Journal, 16(1), 52-81.

Felton, S., Buhr, N., \& Northey, M. (1994). Factors influencing the business student's choice of a career in chartered accountancy. Issues in Accounting Education, 9(1), 131-141.

Haigh, N. (1994). Promoting intellectual independence: A legislative catalyst. Paper presented at the Annual Conference of the Higher Education Research and Development Society of Austrailasia, Canbera, Australia.

Hassall, T., Joyce, J., Montaño, J. L. A., \& Anes, J. A. D. (2005). Priorities for the development of vocational skills in management accountants: A European perspective. Accounting Forum, 29(4), 379-394.

Hermanson, R. H., Deines, D. S., Eldridge, C., Hermanson, D. R., Ivancevich, S. H., \& Williams, D. Z. (1996). Strategies for recruiting the best and brightest students into accounting: American accounting association teaching and curriculum section. Journal of Accounting Education, 14(3), 347-365.

Hill, M.C. (1998). Class size and student performance in introductory accounting courses: Further evidence. Issues in Accounting Education, 13(1), 47-64.

Jackling, B., \& Calero, C. (2006). Influences on undergraduate students' intentions to become qualified accountants: Evidence from Australia. Accounting Education: An International Journal, 15(4), 419-438.

Kavanagh, M., \& Drennan, L. (2007). Graduate attributes and skills: Are we as accounting academics delivering the goods? Paper presented at the Accounting and Finance Association of Australia and New Zealand Annual Conference, Gold Coast, Australia. Retrieved from https://eprints.usq.edu.au/6367/

Lessenger, L., \& Salowe, A. (2001). Healing public schools. Lanham, MD: Scarecrow Press.

Lindsay, D. H., \& Campbell, A. (1995). Accounting research as a determinant of teaching outcomes. Accounting Perspectives, 1(2), 39-56. 
Manakyan, W., \& Tanner, J. R. (1994). Research productivity and teaching effectiveness: Accounting faculty perspective. The Accounting Educators' Journal, 6(2), 1-21.

Marriott, P., \& Marriott, N. (2003). Are we turning them on? A longitudinal study of undergraduate accounting students' attitudes towards accounting as a profession. Accounting Education, 12(2), 113-133.

Millard, P. (2003). Promoting the profession. Chartered Accountant Journal of New Zealand, 82(1), 1-13.

Milner, M. M., \& Hill, W. Y. (2008). Examining the skills debate in Scotland. International Journal of Management Education, 6(3), 1-13.

Murdoch, B., \& Guy, P. W. (2002). Active learning in small and large classes. Accounting Education, 11(3), 271-282.

Parvaiz, G. S., Mufti, O., \& Wahab, M. (2016). Pragmatism for mixed method research at higher education level. Business $\mathcal{E}$ Economic Review, 8(2), 67-78.

Parvaiz, G. S., Mufti, O., \& Wahab, M. (2017). Skills acquisition shortfall: A study of professional accounting education. Business $\mathcal{E}$ Economic Review, 9(2), 135-163.

Pinar, W. F. (2008). What is curriculum theory? Mahwah, NJ: Lawrence Erlbaum Associates Publishers.

Porter, B. A., \& Carr, S. A. (1999). From strategic plan to practical realities: Developing and implementing a zero-based accounting curriculum. Issues in Accounting Education, 14(4), 565-588.

Riodan, M. P., Pierre, E. K., \& Matoney, J. (1996). Some initial empirical evidence regarding the impact of introductory accounting sequence on the selection of accounting as a major. Accounting Education: A Journal of Theory, Practice and Research, 1(2), 127-136.

Schiro, M. S. (2012). Curriculum theory: Conflicting visions and enduring concerns. Boston, USA: Sage Publications.

Seldin, P. (1995). Improving college teaching. Bolton, VA: Anker Publishing Co.

Street, D. L., Baril, C. P., \& Benke, R. L. (1993). Research, teaching, and service in promotion and tenure decisions of accounting faculty. Journal of Accounting Education, 11(1), 43-60.

Wells, P. K. (2006). The supply of accounting graduates in New Zealand. Auckland, NZ: Sprint Print.

Wells, P., Gerbic, P., Kranenburg, I., \& Bygrave, J. (2009). Professional skills and capabilities of accounting graduates: The New Zealand expectation gap? Accounting Education: An International Journal, 18(4), 403-420. 


\section{Appendix 1}

Rate the following elements of constraints towards skills development in accounting education environment?

\begin{tabular}{|c|c|c|}
\hline S. N & Constraining factors & $\begin{array}{l}\text { 1(Strongly disagree) } \\
\text { l(Neutral)-magree) } \\
\text { ly (Strong- }\end{array}$ \\
\hline 1 & $\begin{array}{c}\text { Students enrolling in accounting classes do not have } \\
\text { adequate academic skills to learn at a fast pace }\end{array}$ & 12345 \\
\hline 2 & $\begin{array}{l}\text { Students have an inappropriate (non-serious) attitude } \\
\text { towards learning of professional accounting education }\end{array}$ & 12345 \\
\hline 3 & Classes are packed with a large number of students & 12345 \\
\hline 4 & $\begin{array}{l}\text { Accounting curriculum has an insufficient provision to } \\
\text { allow for the effective development of skills }\end{array}$ & 12345 \\
\hline 5 & $\begin{array}{c}\text { As a shift to research based culture, educators are too } \\
\text { busy with research, such that this impacts their teaching } \\
\text { abilities negatively }\end{array}$ & 12345 \\
\hline 6 & $\begin{array}{l}\text { Teachers' extra efforts are not appreciated in terms of } \\
\text { extra reward by the accounting institutes }\end{array}$ & 12345 \\
\hline 7 & Students have a lack of interest in accounting discipline & 12345 \\
\hline 8 & $\begin{array}{c}\text { People (potential students) have a misperception about } \\
\text { accounting education as being highly mathematical in } \\
\text { nature }\end{array}$ & 12345 \\
\hline 9 & $\begin{array}{l}\text { Accounting institutes are not offering adequate training } \\
\text { opportunities to their academic staff }\end{array}$ & 12345 \\
\hline 10 & $\begin{array}{l}\text { Some of the training organisations are not following } \\
\text { the standard procedures to develop skills in students as } \\
\text { suggested by the accounting bodies }\end{array}$ & 12345 \\
\hline 11 & $\begin{array}{l}\text { For teaching in accounting institutes, it is difficult to } \\
\text { find competent academic staff }\end{array}$ & 12345 \\
\hline 12 & $\begin{array}{c}\text { During articleship, students' get de-motivated due to } \\
\text { inadequate stipend offered by most of the training } \\
\text { organisations }\end{array}$ & 12345 \\
\hline
\end{tabular}


Appendix 2: List of Accounting Education Centers

\begin{tabular}{|c|c|c|}
\hline S. N & Name & No. of Campuses In City \\
\hline \multirow[t]{2}{*}{1} & \multirow{2}{*}{$\begin{array}{l}\text { PROFESSIONALS' ACADEMY OF COMMERCE } \\
\text { (PAC) }\end{array}$} & 1-Lahore \\
\hline & & 1-Peshawar \\
\hline \multirow[t]{2}{*}{2} & \multirow[t]{2}{*}{ AL-HAMD ACADEMY } & 1-Karachi \\
\hline & & 1-Hyderabad \\
\hline \multirow[t]{8}{*}{3} & \multirow[t]{8}{*}{ SKANS SCHOOL OF ACCOUNTANCY (SKANS) } & 1-Karachi \\
\hline & & 1-Faisalabad \\
\hline & & 1-Peshawar \\
\hline & & 1-Islamabad \\
\hline & & 1-Lahore \\
\hline & & 1-Multan \\
\hline & & 1-Sialkot \\
\hline & & 1-Gujranwala \\
\hline \multirow[t]{5}{*}{4} & \multirow{5}{*}{$\begin{array}{l}\text { INSTITUTE OF COST AND MANAGEMENT AC- } \\
\text { COUNTANTS OF PAKISTAN }\end{array}$} & 3-Karachi \\
\hline & & 1-Lahore \\
\hline & & 1-Islamabad \\
\hline & & 1-Multan \\
\hline & & 1-Faisalabad \\
\hline 5 & $\begin{array}{c}\text { COLLEGE OF ACCOUNTING AND MANAGE- } \\
\text { MENT SCIENCES (CAMS) }\end{array}$ & 1-Karachi \\
\hline 6 & TABANI'S SCHOOL OF ACCOUNTANCY (TSA) & 1-Karachi \\
\hline 7 & COLLEGE OF BUSINESS PROFESSIONALS (CBP) & 1-Karachi \\
\hline 8 & FERZAN SCHOOL OF ACCOUNTANCY & 1-Karachi \\
\hline 9 & ESCRIBIR COLLEGE OF ADVANCE STUDIES & 1-Karachi \\
\hline 10 & $\begin{array}{l}\text { ANIS HASSAN SCHOOL OF ACCOUNTANCY } \\
\text { (AHSA) }\end{array}$ & 1-Karachi \\
\hline 11 & $\begin{array}{l}\text { PROFESSIONALS' COLLEGE OF ACCOUNTANCY } \\
\text { (PCA) }\end{array}$ & 1-Faisalabad \\
\hline 12 & SCHOOL OF BUSINESS AND MANAGEMENT & 1-Islamabad \\
\hline 13 & $\begin{array}{c}\text { COLLEGE OF FINANCIAL \& MANAGEMENT } \\
\text { SCIENCES (CFMS) }\end{array}$ & 1-Islamabad \\
\hline 14 & $\begin{array}{l}\text { COLLEGE OF COMMERCE PROFESSIONALS } \\
(\text { (CCP) }\end{array}$ & 1-Faisalabad \\
\hline 15 & WAH COLLEGE OF ACCOUNTANCY & 1-Wah \\
\hline
\end{tabular}




\begin{tabular}{|c|c|c|}
\hline 16 & $\begin{array}{l}\text { NATIONAL COLLEGE OF BUSINESS \& MANAGE- } \\
\text { MENT SCIENCES (NCBMS) }\end{array}$ & 1-Islamabad \\
\hline 17 & $\begin{array}{c}\text { COLLEGE OF ACCOUNTANCY \& PROFESSIONAL } \\
\text { STUDIES (CAPS) }\end{array}$ & 1-Lahore \\
\hline 18 & THE UNIVERSITY OF LAHORE (UOL) & 1-Lahore \\
\hline 19 & RISE SCHOOL OF ACCOUNTANCY & 1-Lahore \\
\hline 20 & $\begin{array}{l}\text { CFE COLLEGE OF ACCOUNTANCY AND FI- } \\
\text { NANCE }\end{array}$ & 1-Lahore \\
\hline 21 & INDUS COLLEGE OF BUSINESS AND FINANCE & 1-Peshawar \\
\hline 22 & PIONEER FINANCE COLLEGE (PC) & 1-Multan \\
\hline 23 & EDUCATION CITY & 1-Karachi \\
\hline 24 & COLLEGE OF PROFESSIONAL STUDIES (CPS) & 1-Karachi \\
\hline 25 & THE TIPS & 1-Faisalabad \\
\hline 26 & ZAKARIYA COLLEGE OF COMMERCE & 1-Multan \\
\hline 27 & $\begin{array}{l}\text { MEHAR ACADEMY FOR PROFESSIONAL STUDIES } \\
\text { (MAPS) }\end{array}$ & 1-Multan \\
\hline 28 & LEADERSHIP COLLEGE OF ACCOUNTANCY & 1-Multan \\
\hline 29 & RISE SCHOOL OF ACCOUNTANCY & 1-Multan \\
\hline 30 & $\begin{array}{l}\text { COLLEGE OF INNOVATIVE MANAGEMENT } \\
\text { SCIENCES, }\end{array}$ & 1-Rawalpindi \\
\hline 31 & SCHOOL OF BUSINESS \& MANAGEMENT & 1-Rawalpindi \\
\hline 32 & COLLEGE OF BUSINESS ADMINISTRATION (CBA) & 1-Lahore \\
\hline 33 & $\begin{array}{c}\text { KNOWLEDGE \& APPLICATION INSTITUTE OF } \\
\text { MANAGEMENT STUDIES (KAIMS) }\end{array}$ & 1-Lahore \\
\hline 34 & THE TIPS FOUNDATION CANAL CAMPUS & 1-Faisalabad \\
\hline 35 & $\begin{array}{l}\text { PUNJAB INSTITUTE OF MANAGEMENT \& TECH- } \\
\text { NOLOGY (PIMAT) }\end{array}$ & 1-Rawalpindi \\
\hline 36 & LEGEND SCHOOL OF ACCOUNTANCY & 1-Lahore \\
\hline 37 & $\begin{array}{l}\text { AL-WADOOD INSTITUTE OF PROFESSIONAL } \\
\text { STUDIES }\end{array}$ & 1-Islamabad \\
\hline
\end{tabular}

